\title{
Development of HOTS-based 2013 Curriculum Assessment Instruments in Elementary School
}

\author{
Marwan Pulungan ${ }^{1}$, Toybah $^{1}$, Vina Amilia Suganda ${ }^{1 *}$ \\ Department of Primary School Teacher education, Faculty of Teacher Training and Education, University \\ of Sriwijaya, Palembang, Indonesia \\ vinaamilia@fkip.unsri.ac.id
}

Abstract

This study aims to develop a HOTS-based 2013 curriculum assessment instrument in the form of questions. The research subjects were fifth-grade students of the elementary school in Palembang. This research activity is development research using the ADDIE development model and the Tessmer evaluation method. The development stages include analysis, design, development, implementation, and evaluation. The prototype evaluation was carried out in stages: self-evaluation, expert reviews, one-to-one evaluation, small group evaluation, and field test evaluation. The results showed that the HOTS-based 2013 curriculum assessment instrument developed was declared valid, with a percentage of $89.5 \%$. The trial results in the one to one and small group stages showed that the assessment instrument (HOTS questions) had a very good level of practicality, namely $84.3 \%$ for the one to one stage, and $83.2 \%$ for the small group stage. The effectiveness of the HOTS-based 2013 curriculum assessment instrument is at a low level, with an average score of 50 . This means that the HOTS questions developed are still not effective in helping students think at higher levels, in this case, the ability to analyze, evaluate and create. This is as a note for researchers to review by carrying out further research.

Keywords: 2013 curriculum; assessment instrument; HOTS.

\section{INTRODUCTION}

Referring to the demands of the 2013 curriculum, it is necessary to develop higher-order thinking skills of students starting from elementary school. However, in reality, it has not been implemented by following the demands of the 2013 curriculum. The results of the research of Rapih and Sutaryadi (2018) stated that $11.43 \%$ of teachers thought that higher-order thinking skills (HOTS) could not be started in elementary school students. Usmaedi (2017) argues that HOTS should have started being taught and trained as early as possible. HOTS is a thinking ability that adjusts a person's cognitive level. Students at elementary school age must be introduced to HOTS according to their cognitive development at that age. Higher-order thinking skills when viewed from the cognitive domain in Bloom's taxonomy are at the level of analyzing, evaluating, and creating. Dafik (2014) 
states that high-order thinking skills which are translated from higher-order thinking skills are thinking activities that involve a high hierarchical cognitive level.

The 2013 curriculum refinement was carried out, among others, on content standards, namely reducing irrelevant material as well as deepening and expanding relevant material for students and enriched with the needs of students to think critically and analytically according to international standards. Other improvements have also been made to the assessment standards, by giving room to the development of an assessment instrument that measures higher-order thinking. Assessment of learning outcomes is expected to help students to improve higher-order thinking skills (HOTS) because high-order thinking can encourage students to think broadly and deeply about the subject matter.

So far, most of the target primary school students tended to use lowerorder thinking skills (LOTS), and the questions were not contextualized. The questions compiled by the teacher generally measure recall skills. When viewed from the context, most of them use the context in the classroom and are very theoretical, and rarely use the context outside the classroom. So that it does not show the relationship between the knowledge gained in learning with real situations in everyday life.

Given the importance of students' higher-order thinking skills, it is necessary to develop a HOTS-based 2013 curriculum assessment instrument that is valid, practical, and effective by following the research and development procedures carried out.

\section{a. Assessment}

Previously, the curriculum in Indonesia used the 2006 curriculum, but now it has changed to the 2013 curriculum. The 2013 curriculum is a refinement, modification, and updating of the previous curriculum (Efendi \& Hsi, 2020). In this change, four elements have changed in the 2013 curriculum, namely graduate competency standards, content standards, process standards, and assessment standards (Oktaviani \& Wulandari, 2019).

Tyler said that assessment (evaluation) is a process of collecting data to determine to what extent, in what way, and what part the educational goals have been achieved (quoted by Arikunto 2013: 3). According to Salamah (2018) educational assessment is the process of collecting and processing information to measure the achievement of student learning outcomes. In the 2013 Curriculum, there are three aspects of assessment, namely affective, cognitive and psychomotor aspects. TIMMS data (Fendrik \& Elvina, 2018 \& Witri, Putra, \& Gustina, 2014) show that students in Indonesia are still unfamiliar with problems that require high-level thinking.

The assessment in the 2013 curriculum is different from the previous assessment, many teachers consider the new method of assessment to be troublesome and burdensome so that 
teachers face problems when conducting authentic assessments in the 2013 curriculum (Safitri \& Oktaviana, 2017).

Assessment in the 2013 curriculum emphasizes measuring the level of thinking of students from low to high; use deep questions, not just rote; measuring student work processes, not just student work; and use student learning portfolios (Subagia \& Wiratma, 2016).

The 2013 curriculum assessment uses authentic assessment, where authentic assessment not only measures aspects of student knowledge but also measures aspects of student attitudes and skills based on learning processes and outcomes (Cahyadi \& Purwandari, 2015). When applying authentic assessments to determine student learning outcomes and achievements, teachers apply criteria related to knowledge construction, observing and experimenting activities, and achievement values outside of school (Alawiyah, 2016). Astuti et al. (2018), wrote that the 2013 curriculum assessment carried out by educators was not only an assessment of learning but also an assessment for learning and assessment as learning. Students' thinking levels are developed starting from the level of thinking to remember, understand, apply, analyze, assess, and be creative. Questions in learning are emphasized on the types of how and why questions that are rational, not on what, where, who, and when questions are factual (Subagia \& Wiratma, 2016).

\section{b. HOTS}

Higher-order thinking skills (HOTS) are a process of deep and broad thinking skills that involve critical and creative processing of information in dealing with and solving complex problems (Ulfah, 2017). In line with that, HOTS is also a thinking ability that arises from a combination of several other complex thinking skills. HOTS is related to critical, logical, reflective, metacognitive, and creative thinking skills (Ramadhana et al., 2018). They are activated when the individual faces an unusual problem, uncertainty, question, or dilemma. The critical thinking disposition reflects a critical spirit which consists of a tendency, or a commitment to act critically, then applying critical thinking skills by paying attention to predetermined criteria and standards (Nirmala et al., 2018). Critical thinking is an activity to analyze ideas in a more specific direction, sharply differentiate, select, identify, study and develop them in a more perfect direction (Alpusari et al., 2020).

In the context of writing HOTS questions, the verb "to determine" could be in the realm of C5 (evaluate) if to make a decision is preceded by a thought process, analyzing the information presented on the stimulus then students are asked to determine the best decision. Even the verb "to determine" can be classified as C6 (to create) if the question demands the ability to develop new problem-solving strategies. Thus, the realm of operational verbs is strongly influenced by what thought processes 
are required to answer the questions given. In the preparation of HOTS questions, a stimulus is generally used. The stimulus is the basis for making inquiries.

In the HOTS context, the stimulus presented should be contextual and interesting. The stimulus can come from global issues such as information technology, science, economy, health, education, and infrastructure issues. The stimulus can also be raised from problems that exist in the environment around the educational unit such as culture, customs, cases in the region, or various advantages that exist in certain areas. HOTS is a major component of creative, critical, and pedagogical thinking so that it can help students develop more innovative ideas, ideal perspectives, and an imaginative perspective (Chinedu et al., 2015). Students engage in HOT when they: visualize problems by making diagrams, separate relevant from irrelevant information in a word problem, look for reasons and causes, justify solutions, see more than one side of the problem with sources of information based on credibility, express assumptions in reasoning and identify logical biases or inconsistencies (Mainali, 2013).

\section{c. Steps to Prepare HOTS Questions}

To write HOTS items, the question writer is required to be able to determine the behavior to be measured and formulate material that will be used as the basis for questions (stimulus) in a certain context according to the expected behavior. Also, the description of the material to be asked (which requires high reasoning) is not always available in textbooks. Therefore, in writing HOTS questions, it takes mastery of teaching material, skills in writing questions (question construction), and teacher creativity in choosing question stimuli according to the situation and conditions of the area around the educational unit. The steps for preparing HOTS questions are analyzing Basic competencies (KD) which can be made HOTS questions, compiling question grids, choosing interesting and contextual stimuli, writing question items according to the question grid, and making scoring guidelines (rubrics) or answer keys. The following is an example of composing HOTS questions for elementary school.

Basic Competencies: Comparing the life cycles of several types of living things and linking them with conservation efforts. Matter Animal growth; Class / Semester IV / 2; Indicator Question Presented the life cycle of a certain animal, students can conclude the events that will occur if a phenomenon of human activity affects the cycle; Cognitive Level 3 (analyze-C4).

The question is what would happen to the growth cycle of the butterfly if the demand for silk had increased sharply?;

Key: The increasing need for silk cloth resulted in an increase in the need for silkworms, resulting in a decrease in the population of cocoons and butterflies. Gradually, butterflies can become extinct. 
Table 1. Answer Keys and Scoring Guidelines:

\begin{tabular}{lc}
\hline Answer & Score \\
\hline If empty or wrong & 0 \\
Silk cloth increases, so the need for silkworms increases & 1 \\
Silk cloth increases, so the need for silkworms increases, resulting in a & 2 \\
decrease in the number of cocoon populations & \\
$\begin{array}{l}\text { Silk cloth increases, so the need for silkworms increases, resulting in a } \\
\text { decrease in the population of cocoons and butterflies }\end{array}$ & 3 \\
$\begin{array}{l}\text { The increasing need for silk cloth increased the need for silkworms, } \\
\text { resulting in a decrease in the population of cocoons and butterflies. }\end{array}$ & 4 \\
Gradually, butterflies can become extinct & \\
\hline
\end{tabular}

Explanation:

This question belongs to cognitive level 3 (analyze-C4) because students have to analyze and combine several new unfamiliar concepts and information.

\section{METHOD}

The research method used is the method of research and development. The choice of this development method is the need for researchers to develop and produce products from the object being developed (e.g., Jalinus \& Alim, 2018).
The $R$ \& $D$ model defined by the ADDIE Model consists of five stages, Analysis, Design, Development, Implementation, and Evaluation. The development procedure used in this study is based on the ADDIE development model (Morrison, et al, 2011) using the formative evaluation method (Tessmer, 1996). From this explanation, it can also be described in the following figure.

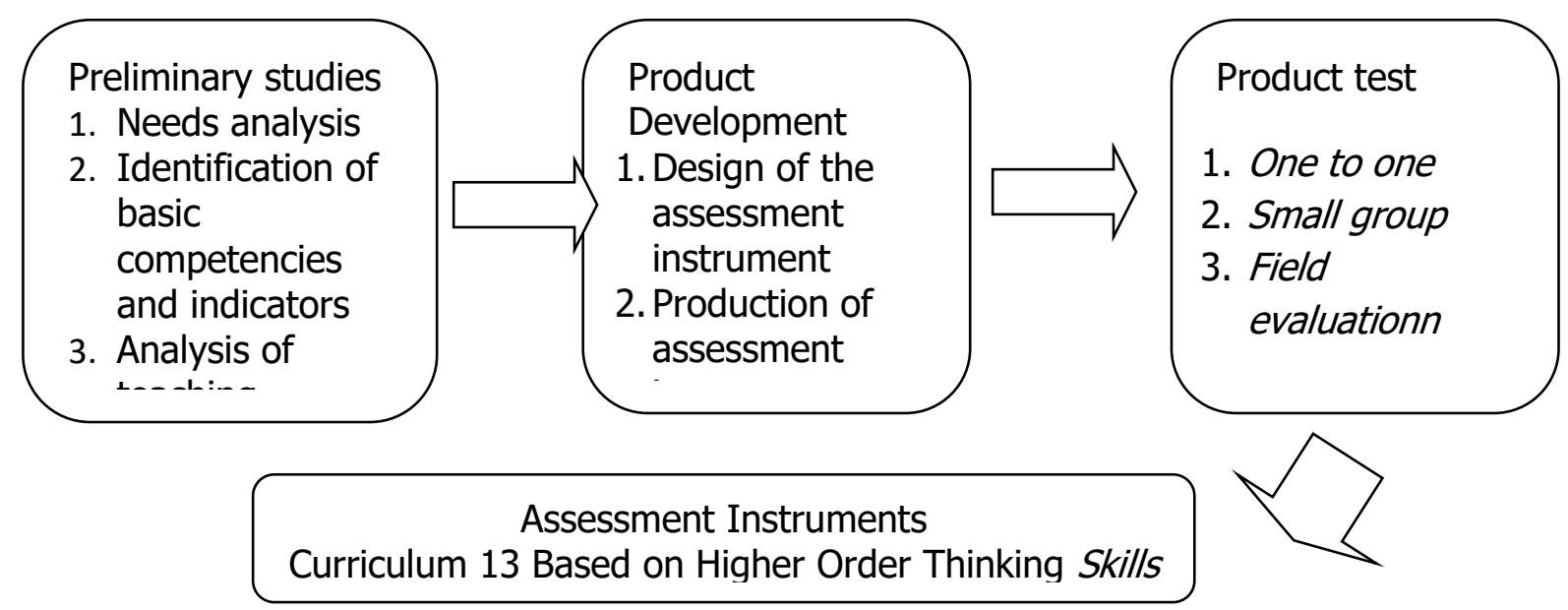


Figure 1.The procedure for developing the 13th curriculum assessment instrument based on higher order thinking skills (HOTS) (adapted from Modification of Sukmadinata, 2007)

\section{RESULT AND DISCUSSION}

\section{Result}

This research is the result of the analysis of the need for HOTS-based assessment instruments for students in elementary schools were taken from questionnaire data filled in by 79 elementary school teachers in South Sumatra and Bangka.

From the needs analysis it was concluded that $98.7 \%$ of the responses agreed to develop a HOTS-based 2013 curriculum assessment instrument in elementary schools, which can be seen from the following diagram.

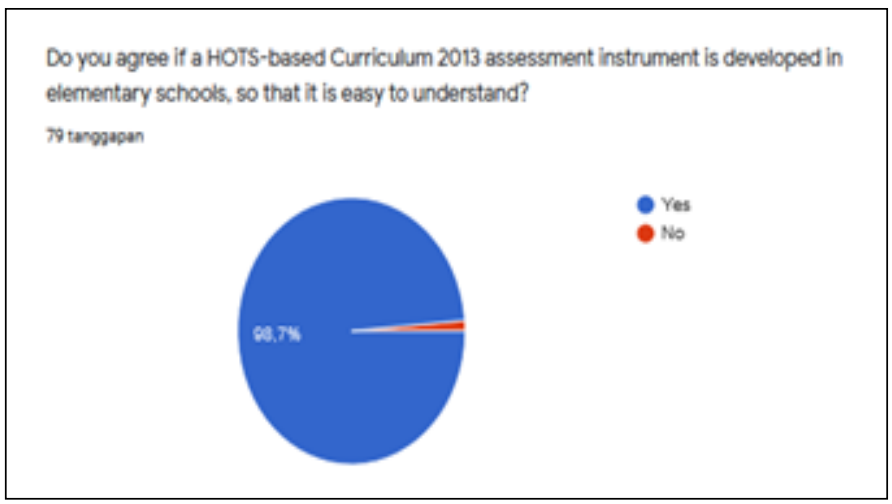

Figure 2. Percentage of elementary school teachers who stated that they needed HOTSbased 2013 curriculum assessment instruments for students in elementary schools.

After obtaining the results of the needs analysis, the next step is to make a design (design) of a learning model development product consisting of Question Cards and HOTS-based Assessment Instruments.

The research product that has been designed is then developed to produce a product before being tested. The development carried out is by validating experts and practitioners on the products that have been designed. The validation includes material validation and question design. Based on the final results of the validation carried out, it can be concluded that the research product that has been developed in the form of a HOTS-based research instrument is declared valid and can be tested. The limited trial was conducted in grade $\mathrm{V}$ elementary school.

\section{a. Validity test}

The product validity test was carried out by 6 validators consisting of 5 experts and one class teacher as a practitioner. Validation will be carried out on the material and question design. The material expert validators are from the fields of elementary school mathematics, elementary school Indonesian language, elementary school 
natural science, civic education and elementary school social science, as well as fifth grade teachers of one of the public elementary schools in Palembang as practitioners.

The following is an example of an instrument for HOTS questions before being validated and after being validated by experts. In the form of question cards, Natural Science Subjects (IPA); Class / Semester IV / 1; Curriculum 2013. Basic Competencies 3.5 Identify various energy sources, changes in the form of energy, and alternative energy sources (wind, water, solar, geothermal, organic fuels, and nuclear) in everyday life; Material Various energy sources, changes in the form of energy, and alternative energy sources; Question Indicators Presented four pictures of electronic objects, students can explain the benefits of electrical energy for each image so that objects in the image can be used; Cognitive Level C4 (Analyze).
Problem: Observe the following pictures of electronic objects!

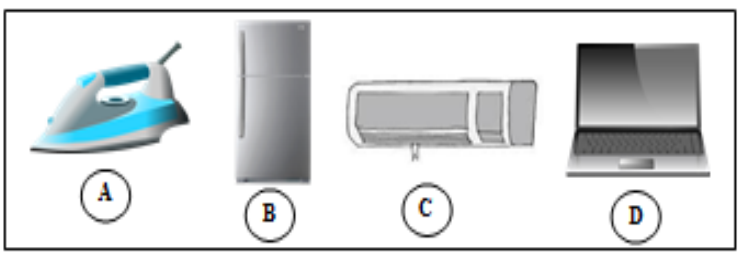

Based on the four pictures above, explain the benefits of electrical energy for each image so that the objects in the picture can be used!

The validator's note is that the cognitive level is not by following the questions, so it is revised to Based on the four pictures above if asked to replace it with alternative energy. Which electronic item do you think can be replaced!

The validation sheet for experts in assessing the HOTS-based 2013 curriculum assessment instrument is in table 2 . The following is a recapitulation of the results of product validation shown in table 3.

Table 2. The assessment aspect is in the instrument validation sheet

\begin{tabular}{cll}
\hline Number & Aspect of Assessment & \multicolumn{1}{c}{ Criteria } \\
\hline 1 & HOTS & Development of HOTS-based PROBLEMS \\
2 & Construction (Language) & $\begin{array}{l}\text { 1. Use of Language } \\
\text { 2. Clarity of Sentences } \\
\text { 1. Complete pictures, } \\
\text { 2. Display Design }\end{array}$ \\
\hline
\end{tabular}


Table 3. Recapitulation of HOTS-Based Assessment Instrument Validation Results

\begin{tabular}{|c|c|c|c|c|}
\hline \multirow{2}{*}{ Validator/Expert } & \multirow{2}{*}{$\begin{array}{l}\text { Maximum } \\
\text { Score }\end{array}$} & \multicolumn{2}{|c|}{ Score / Percentage of validation } & \multirow{2}{*}{ Conclusion } \\
\hline & & I & II & \\
\hline $\begin{array}{l}\text { elementary school } \\
\text { mathematics }\end{array}$ & 24 & 24 / 100\% & - & Valid \\
\hline $\begin{array}{l}\text { elementary school } \\
\text { indonesian lanquage }\end{array}$ & 24 & $20 / 83,3 \%$ & - & Valid \\
\hline $\begin{array}{l}\text { elementary school } \\
\text { natural science }\end{array}$ & 24 & $21 / 87,5 \%$ & - & Valid \\
\hline Civic education & 24 & $20 / 83,3 \%$ & - & Valid \\
\hline $\begin{array}{l}\text { elementary school } \\
\text { social science }\end{array}$ & 24 & $19 / 79,1 \%$ & $21 / 87,5 \%$ & Valid \\
\hline Practices & 24 & $23 / 95,8 \%$ & - & Valid \\
\hline
\end{tabular}

Table 4. Student Response Questionnaire Sheet on HOTS-Based Questions

\begin{tabular}{|c|c|c|c|c|c|}
\hline \multirow[t]{2}{*}{ Number } & \multirow[t]{2}{*}{ Statement } & \multicolumn{4}{|c|}{ Rating Scale } \\
\hline & & SS & $S$ & TS & STS \\
\hline 1. & $\begin{array}{l}\text { The questions presented are easy to } \\
\text { understand }\end{array}$ & & & & \\
\hline 2. & $\begin{array}{l}\text { The command for each question is } \\
\text { clear }\end{array}$ & & & & \\
\hline 3. & $\begin{array}{l}\text { The command for each question is } \\
\text { difficult to understand }\end{array}$ & & & & \\
\hline 4. & $\begin{array}{l}\text { The language used in the questions } \\
\text { uses standard Indonesian }\end{array}$ & & & & \\
\hline 5. & $\begin{array}{l}\text { The language used in the questions } \\
\text { has many meanings }\end{array}$ & & & & \\
\hline 6. & $\begin{array}{l}\text { Instructions for working in questions } \\
\text { are easy to understand }\end{array}$ & & & & \\
\hline 7. & $\begin{array}{l}\text { Instructions for working on confusing } \\
\text { questions }\end{array}$ & & & & \\
\hline 8. & $\begin{array}{l}\text { The images presented in the questions } \\
\text { are clear and attractive }\end{array}$ & & & & \\
\hline
\end{tabular}

Information: SS (strongly agree), S (agree), TS (disagree), and STS (totally disagree) (Hestiana, 2018)

a. Pilot Experiment (One to One dan Small Group)

The limited trial of the assessment instrument was carried out in the form of giving a questionnaire, to determine the practicality of the HOTS questions that had been designed. The practicality measurement of HOTS questions will be 
seen from the questionnaire sheets. The questions in the student questionnaire can be seen in table 4 above. That the students filled out after 3 students (stage one to one ) see the HOTS questions provided. Then from the results of the questionnaire, revisions will be carried out if difficulties are found, then proceed with giving a questionnaire to 8 (eight) students (small group stage) to re-measure the practicality of HOTS questions that have been revised from the previous stage. Student responses in the one to one stage to HOTS questions with a total score of 81 or $84.3 \%$, if converted into practicality criteria then they are in the very good category, meaning that the HOTS-based assessment instrument developed can be practical to use. Student responses in the small group stage to HOTS questions with a total score of 213 or $83.2 \%$, if converted into practicality criteria, they are in the very good category, meaning that the HOTSbased assessment instrument developed can be practical to use.

\section{b. Field Test Evaluation}

The field test or field test or large class test is an implementation stage or a continuation after one to one and small groups. At this stage students are given questions related to HOTS questions, the results of this stage will measure the effectiveness of the HOTS questions that have been made. The results of this field test evaluation obtained an average score of 50 with the less effective category.

\section{Discussion}

Utilization of the 2013 curriculum assessment is used to form positive attitudes of students and as a means to increase student interest and motivation, uniform students' thinking skills by grouping students based on their respective achievements, providing information to parents in knowing progress as a means of improvement in the learning implementation plan, a means to optimize the learning process that takes place in improving the learning process so that students achieve successful learning outcomes (Sutama et al., 2017). The 2013 curriculum assessment will be meaningful for teachers in determining the best ways so that all students can achieve the final result, even with different time units (Umami, 2018).

The development of an assessment instrument based on HOTS Curriculum 2013 has been carried out in three stages, namely preliminary studies, product development, and product testing. This HOTS-based assessment instrument has gone through the expert review stage involving three validators including material experts, media experts, and linguists. After being declared valid and feasible in the trial, it was carried out in three stages, namely one to one, small group, and field evaluation. 
At the development stage, the HOTS question assessment instrument prototype has been completed, then validation is held by the validators. This is done to determine the validity level of the HOTS assessment instrument (HOTS question). At this stage, the average validation results obtained according to experts 5 (field of study) and practitioners are the total score of 129 or $89.5 \%$. The validity test was carried out 2 (two) times, namely the validity test by an SD social studies expert. In the validity assessment, there were comments from experts, comments given by the validators became a reference for researchers before testing HOTS questions at the field evaluation stage.

At the product trial stage, the stages that have been carried out are one to one and small group trials. In the one to one stage, it is known that the HOTS questions have a very good level of practicality with a student questionnaire percentage of $84.3 \%$. After the one to one stage, the next stage was a small group with a practicality level of HOTS questions of $83.2 \%$ in the very good category.

The final stage of the product testing activity is field evaluation. At this stage, students in large classes work on HOTS questions to measure the effectiveness of the HOTS questions developed. From the average test results obtained an average value of 50 . So it can be concluded that this HOTS question has a low level of effectiveness. This is not in accordance with the expectations of the researcher, the cause of the field evaluation results is in the low effectiveness category, because the fifth-grade students of SD Negeri 1 Palembang are 5 students, but only 15 students only fill in or work on the questions. The reason is due to the current condition of the Covid-19 pandemic, learning in schools is carried out online and information about giving HOTS questions is only given to students who have long-distance communication tools using the internet, while other students are not in a situation where it is possible to be given HOTS questions. This information the researcher obtained from the class teacher that the researcher used, and the decision to give questions only to students who allowed to be given HOTS questions was also a consideration chosen between the class teacher and the researcher.

The information obtained from the class teacher is to provide daily assignments for students who cannot communicate remotely, namely their parents who come to school to ask for assignments from the class teacher, and the collection of the assignments a week after the assignments are given. This is an excuse not to give questions to students who are unable to communicate remotely.

Thus, from several stages that have been passed in the development of the 2013 HOTS curriculum-based assessment, it can be said that this product is valid, practical, but low effective. This is a note for future researchers' improvement because 
thinking skills are important for students to solve problems in the learning process so that it fosters competitive thinking, develops students' intellectuals, and helps avoid mistakes in thinking (Heong et al., 2011). The teacher plays a role in practicing the strong application of HOTS to improve students' thinking skills (Baharin et al., 2018). HOTS is an important aspect of the learning process and students need to be evaluated to determine the extent of HOTS achievement in students in the learning process (Hadi et al., 2018). Thinking skills are essential for success and functioning effectively in every aspect of an individual's life in society and in an era of ever-changing knowledge (Hugerat \& Kortam, 2014).

\section{CONCLUSION}

Based on the results of the research and discussion, it can be concluded that the HOTS-based 2013 curriculum assessment instrument developed was declared valid by the validators with a percentage of $89.5 \%$. The trial results in the one to one and small group stages showed that the assessment instrument (HOTS question) had a very good level of practicality, namely $84.3 \%$ for the one to one stage, at the small group stage the percentage was $83.2 \%$. The effectiveness of the HOTS-based 2013 curriculum assessment instrument is at a low level with an average value of 50 , meaning that the HOTS questions developed are still not effective in helping students think at high levels, in this case, the ability to analyze, evaluate and create. This is a note for researchers for further research, namely how to improve the thinking skills of elementary school students at a higher level, especially those related to HOTS abilities.

\section{REFERENCES}

Alawiyah, T. (2016). Kendala Guru Dalam Menerapkan Penilaian Autentik di SD Kabupaten Pidie. Jurnal Ilmiah Mahasiswa Pendidikan Guru Sekolah Dasar FKIP Unsyiah, 1(1), 147-157.

Alpusari, M., Mulyani, E. A., Hermita, N., \& Putra, E. D. (2020). Improving Fourth Grade Students' Critical Thinking Skills with MIKIR Approach. Journal of Teching and Learning in Elementary Education (JTLEE), $3(2)$, 199. https://doi.org/10.33578/jtlee.v3i2. 7850

Arikunto, S. (2013). Dasar-Dasar Evaluasi Pendidikan (edisi revisi). Bumi Aksara, Jakarta: xii $+310 \mathrm{hlm}$ Bola J. I dan Pah. D. N. (1985). Keterampilan Bertanya Dasar dan Lanjut. Jakarta: CV. Fortuna.

Astuti, D. A., Haryanto, S., \& Prihatni, Y. (2018). Evaluasi implementasi kurikulum 2013. Wiyata Dharma: Jurnal Penelitian Dan Evaluasi Pendidikan, 6(1), 13. https://doi.org/10.30738/wd.v6i1.3 $\underline{353}$

Baharin, N., Kamarudin, N., \& Manaf, U. 
K. A. (2018). Integrating STEM Education Approach in Enhancing Higher Order Thinking Skills. International Journal of Academic Research in Business and Social Sciences, $8(7)$. https://doi.org/10.6007/ijarbss/v8$\mathrm{i} 7 / 4421$

Cahyadi, F., \& Purwandari, A. (2015). Penilaian Autentik Mata Pelajaran Matematika Kurikulum 2013 Guru Kelas IV Kota Semarang. Malih Peddas (Majalah Ilmiah Pendidikan Dasar), 4(2), 35-42. https://doi.org/10.26877/malihped das.v4i2.537

Cinedu, C. C., Kamin, Y., \& Olabiyi, O. S. (2015). Strategies for Improving Higher Order Thinking Skills in Teaching and Learning of Design and Technology Education. Journal of Technical Education and Training, $7(2), 43$.

Dafk. (2014). Keterampilan Berpikir Tingkat Tinggi (HOTS). $1 \mathrm{hlm}$. http://dafikfkip- unej.org/berita199-keterampilan-berpikir-tingkattinggi-hots.html. 01 Desember 2015, pk. 18.45.

Efendi, M. Y., \& Hsi, N. L. (2020). The Comparison of Elementary Curriculum Education between Indonesia and Singapore. Journal of Teching and Learning in Elementary Education (JTLEE), 3(1), 22-34. https://doi.org/10.33578/jtlee.v3i1. 7323

Fendrik, M., \& Elvina, E. (2018). The Impact of Visual Thinking Approach to Promote Elementary Students' Problem Solving Skill in Mathemathics. Journal of Teaching and Learning in Elementary Education (JTLEE) , 1(2), 108. https://doi.org/10.33578/jtlee.v1i2. 5881

Hadi, S., Retnawati, H., Munadi, sudji, apino, E., \& Wulandari, N. f. (2018). The Difficulties of High School Students in Solving HigherOrder Thinking Skills Problems. Problem of Education in The 21st Century, 76(4), 520-532.

Hestiana. (2018). Pengembangan Soal Higher Order Thinking Skills (HOTS) pada Mata Pelajaran IPA di Kelas $V$ Sekolah Dasar. Skripsi, Indralaya: FKIP Unsri.HIm: 11. Heong, Y. M., Othman, W. B., Yunos, J. B. M., Kiong, T. T., \& Mohamad, M. M. B. (2011). The Level of Marzano Higher Order Thinking Skills among Technical Education Students. International Journal of Social Science and Humanity, 1(2), 121125.

Hugerat, M., \& Kortam, N. (2014). Improving higher order thinking skills among freshmen by teaching science through inquiry. Eurasia Journal of Mathematics, Science and Technology Education, 10(5), 447-454. https://doi.org/10.12973/eurasia.2 014.1107a

Jalinus, J., \& Alim, J. A. (2018). Pengembangan Pembelajaran Media Interaktif Berbasis Komputer Pada 
Topik Bilangan Bulat Untuk Siswa Sd Pendidikan Matematika Fkip Unri. Tunjuk Ajar: Jurnal Penelitian IImu Pendidikan, 1(1), 14-26.

Mainali, B. P. (2013). Higher Order Thinking in Education. Academic Voices: A Multidisciplinary Journal, 2(1), $\quad$ 5-10. https://doi.org/10.3126/av.v2i1.82 77

Morrison, G.R., Ross, S.M., Kalman, H.K., \& Kemp, J.E. (2011). Designing Effective Instruction Sixth Edition. Hoboken: John Willey \& Sons, Inc.

Nirmala, S. D., Rahman, R., \& Musthafa, B. (2018). Students' Elementary Literacy Skill And Critical Thinking Skill Supported By School Literacy Program (SLP). Journal of Teaching and Learning in Elementary Education (JTLEE), 1(2), 97. https://doi.org/10.33578/jtlee.v1i2. 5880

Otaviani, N. M., \& Wulandari, I. (2019). Implementation of Standard of Graduate Competence in The Curriculum 2013 in Elementary Schools. Journal of Teching and Learning in Elementary Education (JTLEE), 2(2), 126-135. https://doi.org/10.33578/itlee.v2i2. $\underline{7719}$

Apih, S. \& Sutaryadi. (2018). Perpektif guru sekolah dasar terhadap Higher Order Tinking Skills (HOTS): pemahaman, penerapan dan hambatan. Premiere Education: Jurnal Pendidikan Dasar dan Pembelajaran. p-ISSN: 2088-5350,
e-ISSN: 2528-5173, Vol 8 No. 1. Doi: $10.25273 /$ pe.v8i1.2560

Ramadhana, N. A., Rozimela, Y., \& Fitrawati. (2018). High Order Thinking Skills-Based Questions in The Test Items Developed by Senior High School English Teachers of Padang. Journal of English Language Teaching, 74), 721-731.

https://doi.org/10.24036/jelt.v7i4.1 01757

Safitri, D., \& Oktaviana, M. (2017). Implementasi Penilaian Autentik Kurikulum 2013 (Studi Kasus Guru IPS di Smp Labschool Jakarta). Edukasi IPS, 1(1), 31-40. https://doi.org/10.21009/EIPS.011 04Salamah, Umi. (2018). Penjaminan Mutu Penilaian Pendidikan. Jurnal Evaluasi. pISSN: 2580-3387, e-ISSN: 25182886, Vol 2 No. 1.

Subagia, I. W., \& Wiratma, I. G. L. (2016). Profil Penilaian Hasil Belajar Siswa Berdasarkan Kurikulum 2013. JPI (Jurnal Pendidikan Indonesia), 5(1), 54. https://doi.org/10.23887/jpiundiksha.v5i1.8293

Sukmadinata, S., \& Nana S. (2007). Metode Penelitian Pendidikan. Bandung: PT Remaja Rosdakarya;

Sutama, S., Sandy, G. A., \& Fuadi, D. (2017). Pengelolaan Penilaian Autentik Kurikulum 2013 Mata Pelajaran Matematika di SMA. Manajemen Pendidikan, 12(1), 114.

https://doi.org/10.23917/jmp.v12i1 
.2967

Tessmer, (1996). Planning and Conducting Formative Evaluation; inproving the quality of education and training). (Martin Tessmer(Kogan Page Limited). (Psikologi Belajar). Faculty of Educational Science andTechnology, University of Twente, London.

Ulfah, H. A. (2017). Melatih Keterampilan Berpikir Tingkat Tinggi dalam Pembelajaran Matematika Pada Siswa Sekolah Dasar. TERAMPIL: Jurnal Pendidikan Dan Pembelajaran Dasar, 4(2), 143-156. https://doi.org/10.24042/terampil.v 4i2.2222.

Umami, M. (2018). Penilaian Autentik Pembelajaran Pendidikan Agama Islam dan Budi Pekerti dalam
Kurikulum 2013. Jurnal Kependidikan, 6(2), 222-232. https://doi.org/10.24090/jk.v6i2.22 59

Usmaedi, U. (2017). Menggagas Pembelajaran HOTS Pada Anak Usia Sekolah Dasar. Jurnal Pendidikan Sekolah Dasar (JPsd). p-ISSN:2540 9093, e-ISSN:25030558, Vol 3 No 1.

Witri, G., Putra, Z. H., \& Gustina, N. (2014). Analisis kemampun siswa Sekolah Dasar dalam menyelesaikan soal-soal matematika Model the Trends for International Mathematics and Science Study (TIMSS) di Pekanbaru. Primary: Jurnal Pendidikan Guru Sekolah Dasar, 3 (1), 32-39. 